\title{
Min far fant selv veien til den beste død
}

\author{
Da min far fikk diagnosen lungefibrose, ble han forespeilet en gradvis kvelning. Hans egne valg på slutten \\ av livet ga i stedet overraskende velvære, både psykisk og fysisk.
}

Far var 87 år. Livsglad, forelsket og kvikk i replikken. Sykdommen utviklet seg raskt, og pusten ble stadig dårligere. Far aksepterte at sykdommen måtte gå sin gang, men ville gjøre spådommene om en plagsom død til skamme. Han hadde tro på at han kunne finne ut av dette selv, hvis han kunne bo hjemme. Han ville ikke på sykehus eller sykehjem.

Far manøvrerte seg gjennom de siste ukene, med oss nærmeste i nærheten. Han innrettet seg etter kroppens signaler. Han brukte ingen medisiner. Vi var typiske pårørende, som $\mathrm{i}$ beste mening prøvde å få $\mathrm{i}$ ham mat. Maten ga ham voldsomme hostekuler. I tillegg var kroppen så nedbrutt av sykdom at den ikke klarte å bearbeide maten. Derfor bestemte han seg for å slutte helt å spise og drikke så snart han ble sengeliggende. Det ville skjerme kroppen mot unødige plager og la naturen gå sin gang. Dette fungerte veldig godt for far.

Den dagen far ble sengeliggende, sluttet han å spise. Han fortsatte å barbere og vaske seg, pusse tenner, ha på rene klær og være fin på håret. Dette ordnet han selv, hver eneste dag. Han hadde også vært på toalettet for siste gang. Kroppen var lett og fin etterpå. Det ble ingen flere dobesøk, bare urinflaske.

Den andre dagen sluttet han å drikke. Far hostet mye mindre, og pusten var fin når han lå i ro i sengen. Han lurte på når hjernen ville bli svekket etter at han sluttet å drikke. Han forsket litt på seg selv og var seg selv lik. Interessert fulgte han med på hvor mye urin som kom i flasken, og hvordan den så ut. Og han lurte på hvordan nyrene tålte dette.

Denne dagen tok han avskjed med kjæresten. De lå og kikket på bilder på mobiltelefonene sine og snakket om den fine tiden de hadde hatt - og var lykkelig for den.

Den tredje dagen svarte han på SMS fra barnebarna. Lykkelig og takknemlig over alle kjærlighetserklæringene lurte han på om han ikke måtte avlyse dette dødsfallet.

Den fjerde morgenen utbrøt han med glimt i øyet «Farsken! Jeg lever jo enda.
Er i så fin form. Dette går jo feil vei!». Han syntes dette var spennende. Far var ikke troende og mente at det er svart før vi fødes og blir svart igjen når vi dør. Han var ikke redd døden og spøkte med at han snart fikk vite om det var noe på den andre siden.

Far mente at man selv, om mulig, bør få velge hvordan man vil leve de siste dagene av livet, og at det kan gjøre døden lettere.

\section{«Denne dagen tok han avskjed med kjæresten»}

Han ville gjøre det han gjorde - ikke bare for seg selv - men for alle andre i samme situasjon. Og han ville at jeg skulle skrive om det.

Den femte natten var kald og dårlig. Han hostet mye. Jeg masserte føttene hans. Det hjalp. Vi tok et par skjeer vodka og sprite. Stemningen var god, og far fortalte om båtturene sine langs norskekysten. Om kvelden falt han bort et par ganger, men kom fort over det. Han sovnet og hadde det bra. Han var svært takknemlig for at vi i familien fulgte han gjennom denne tiden, slik at han kunne være hjemme.

Den sjette morgenen ropte far med fryd i stemmen «Det har vært ei kjempemessig natt. Har sovet veldig godt. Hadde følelsen av å våkne i sakte film og var så fin i hele kroppen. Ingen hoste».

Denne kvelden ble han mer sliten, men humøret var bra. Han syntes at han hadde fått brukt de siste dagene godt. Han tok et aller siste farvel med kjæresten på telefonen: «Ha det bra, min elskede». Han håpet å sovne for godt denne kvelden.

Den syvende dagen våknet jeg av duringen av barbermaskinen. Far tok som vanlig morgenstellet. Han lå velstelt og fin i sengen da jeg sto opp.
Etter én uke uten mat og seks dager uten drikke ble far stadig svakere. Han falt bort, så utydelig og trodde han skulle dø. Han klarte så vidt å snakke, men så ofte på meg med et smil. Sa det var beroligende at jeg satt der og heklet. Fuktet selv munnen med en klut og hadde det fint og var fornøyd.

Plutselig grep far mobiltelefonen og satte på musikken han og kjæresten hadde danset etter på Gran Canaria to måneder tidligere. Han så lurt på meg, smilte lykkelig og la mobiltelefonen på hyllen over sengen - for godt.

Den åttende dagen trodde vi han skulle dø. Han hadde synsforstyrrelser, fantaserte litt og ville holde meg $\mathrm{i}$ hånden. Strevde med pusten et par ganger. Pusteøvelser hjalp, og han sovnet rolig, men åpnet stadig øynene og smilte. Tydelig glad for at jeg var der. Han ville til og med ha med seg overskriftene fra Avisa Nordland, og ga signal når han ville jeg skulle bla videre.

Utpå kvelden ble han urolig i kroppen. Slutten nærmet seg. Føttene ble marmorert. Jeg spurte om han ville ha en stikkpille for å få ro. Det ville han. Stesolid $5 \mathrm{mg}$ gjorde underverker. Far sovnet rolig og fint.

Den niende morgenen våknet jeg av at far pustet uregelmessig. Søsteren min og jeg rakk akkurat frem til sengen hans før han døde. Han døde fredelig og rolig en helt naturlig død - akkurat som han håpet.

\section{Elisabeth Arntzen}

elisarnt@online.no

\section{Elisabeth Arntzen (f. 1955) er datter av den} avdøde.

Forfatter har fylt ut ICMJE-skjemaet og oppgir ingen interessekonflikter.

Mottatt 13.2. 2017, første revisjon innsendt 22.2. 2017, godkjent 13.3. 2017. Redaktør: Kaveh Rashidi. 